\title{
Revitalizace budov V konceptu Smart Prague
}

\section{REVITALIZATION OF BUILDINGS IN CONCEPT OF SMART Prague}

\author{
Michal Rohlena ${ }^{1}$ \\ ${ }^{1}$ Ecoten, smart energy solutions, Lublanska 1002/9, 12000 Prague 2, \\ Czech Republic, rohlena@ecoten.cz
}

\begin{abstract}
Abstrakt - CZ
Článek pojednává o zpracování studie na pilotní projekt revitalizace vybraných objektů konceptu SMART Prague. $K$ vizi konceptu SMART Prague a jeho osy SMART Infrastructure je možné se přibližit realizací budov ve fondu hlavního města Prahy a to především z důvodu vysoké efektivity dopadů opatření, která se dají vobecných principech replikovat. Revitalizace nezahrnuje pouze ošetření obálky budovy a technických systémů, resp. minimalizace environmentálních dopadů, ale také management spotřeb a využití vody, půdy, zeleně funkčně spojených s budovou, užití ekologicky certifikovaných materiálů ovlivňujících mimo jiné kvalitu vnitřního prostředí, zlepšení komfortu uživatelů a bezpečnosti, pozitivní stimulace vnitřním prostředím, management nákladů životního cyklu, především provozních nákladů a odpadů, řešení management vazeb na bezprostřední okolí.
\end{abstract}

Klíčová slova - CZ

Smart City, budovy, Praha, $\mathrm{CO}_{2}$

\section{Abstract - EN}

The article deals with the preparation of a study on a pilot project for the revitalization of selected SMART Prague buildings. The vision of the SMART Prague concept and its SMART Infrastructure axis can be approached by building projects in the Prague capital fund, mainly because of the high efficiency of the impact of measures that can be replicated in general principles. Revitalization does not only cover the treatment of building envelope and technical systems, minimization of environmental impacts, but also management of water and utilization of water, soils, greenery functionally connected to the building, use of environmentally certified materials influencing, among other things, the quality of the indoor environment, improvement of user and safety, positive stimulation in the internal environment, lifecycle management, and waste management solutions to the immediate vicinity.

\section{Keywords - EN}

Smart City, buildings, Prague, $\mathrm{CO}_{2}$

\section{JEL Classification}

$\mathrm{H} 72, \mathrm{Q} 48, \mathrm{Q} 51$

DOI: https://doi.org/10.14311/bit.2017.01.04

Editorial information: journal Business \& IT, ISSN 2570-7434, CreativeCommons license @c) (1) published by CTU in Prague, 2017, http://bit.fsv.cvut.cz/ 


\section{SMART Prague}

Hlavní město Praha je ekonomicky zdaleka nejvyspělejším regionem České republiky a centrem nadregionálního významu. Jako takové zásadním způsobem přispívá k rozvoji konkurenceschopnosti a ekonomického růstu středoevropského regionu. Poskytuje hustou sít veřejných služeb a to nejen pro občany Prahy, ale pro všechny obyvatele republiky. Je také centrem vzdělanosti, nebot' je sídlem $2 / 3$ všech institucí vědy a výzkumu a na jejím území se realizuje 40 \% všech výdajů spojených s touto oblastí v České republice. (Tencar, Zadina, 2013)

Nejen tyto charakteristiky vybízejí Prahu k hledání východisek z existujících problémů, která zajistí dlouhodobé řešení prostřednictvím inteligentních a systematických opatření. Jedním ze zásadních problémů Prahy je energetická náročnost nemovitostí, které jsou v jejím vlastnictví. Řešením je hledání úspor ve spotřebě energií v nemovitostech, což v minulosti znamenalo, že daná nemovitost je zateplena, případně jsou vyměněny výplně stavebních otvorů (okna, dveře). (MACEK, D. and DOBIÁŠ, J., 2014) Takový stavební zásah sice snízí spotřebu energií, není však v okamžiku zásahů do budovy plně využit potenciál dalších úspor, které jsou dosažitelné využitím synergií těchto opatření s dalšími systémy (fotovoltaika, BMS systémy apod.) a také do budoucna neumožnuje dosažení synergií v rámci systému Smart City. Přitom podpora inteligentních budov mimo jiné cílí na prrípravu plně integrovatelných prvků budoucího Smart Grid, jakožto subsystému budoucího Smart City ztělesněného konceptem Smart Prague. (Tencar, Zadina, 2013)

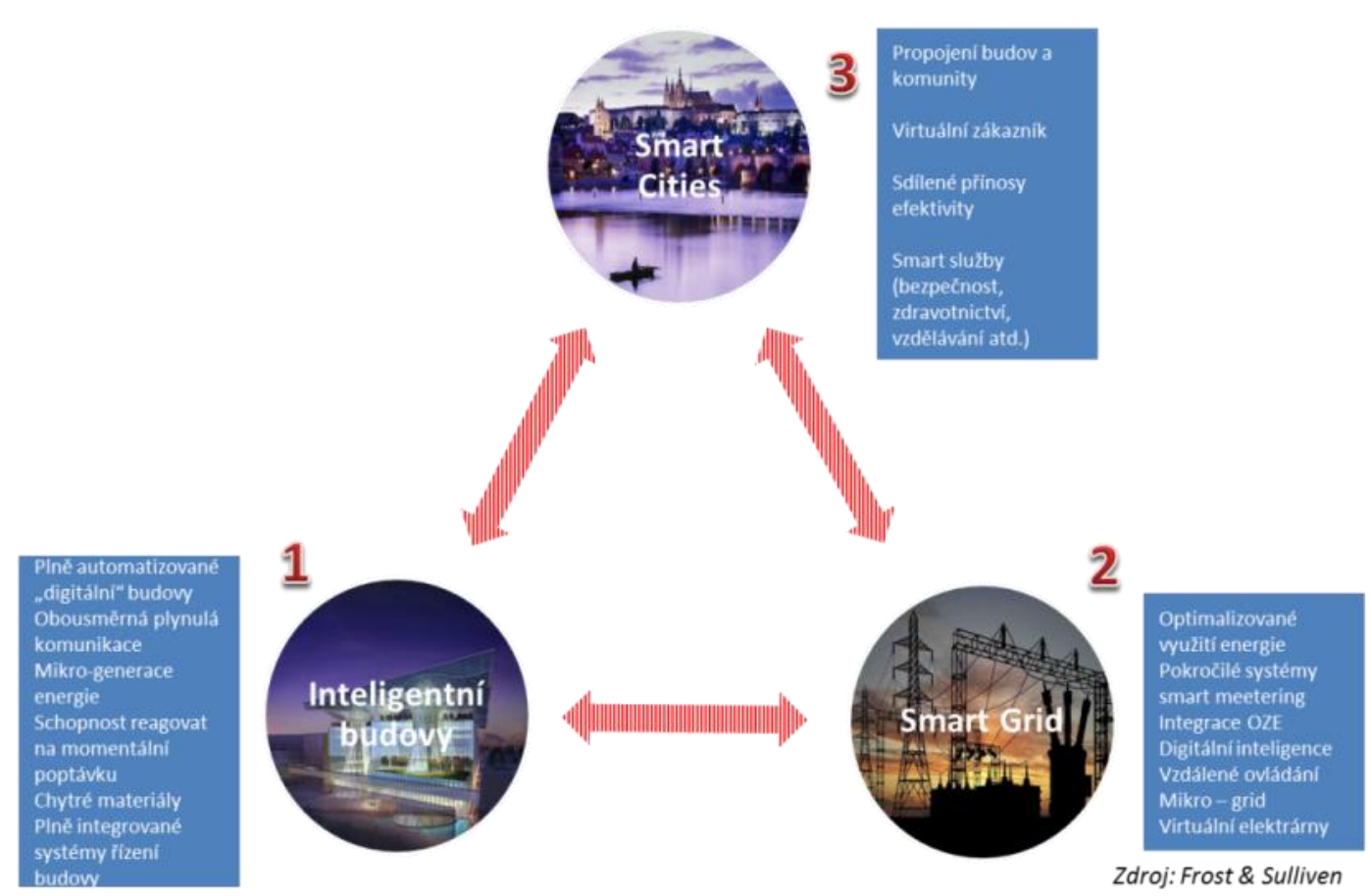

Figure 1: Koncept Smart City

\section{Operační program Praha - pól růstu}

Jedním z důvodů pro zpracování studie transformace objektů je možnost využít finančních prostředků OP Praha - pól růstu. Tento operační program v prioritní ose 2 alokuje finanční částku ve výši 2 mld. Kč na provedení úsporných opatření na budovách a dopravě. Značná část těchto finančních prostředků by byla využita na realizaci pilotního projektu transformace objektů konceptu SMART Prague.

Operační program stanovuje následující indikátory hodnocení. 
Tab 1: Sledované indikátory převzaté z OP pro období 2014 - 2020

\begin{tabular}{|c|c|c|c|c|c|c|c|}
\hline \multicolumn{8}{|c|}{ Indikátory } \\
\hline ID & Indikátor & měrná jednotka & výchozí hodnota & výchozí rok & cílová hodnota (2023) & zdroj dat & $\%$ dopad \\
\hline $\begin{array}{l}\text { Nařízení } \\
\text { Evropského } \\
\text { parlamentu a } \\
\text { Rady pro EFRR }\end{array}$ & $\begin{array}{l}\text { Snížení spotřeby } \\
\text { primární energie } \\
\text { veřejných budov }\end{array}$ & kWh/rok & 33624000 & 2014 & 16269000 & $\begin{array}{l}\mathrm{R} O \mathrm{O} \text { z MS } \\
\mathrm{OP}\end{array}$ & $-52 \%$ \\
\hline $\begin{array}{l}\text { Nařízení } \\
\text { Evropského } \\
\text { parlamentu a } \\
\text { Rady pro EFRR }\end{array}$ & $\begin{array}{l}\text { Odhadované snížení } \\
\text { produkce } \\
\text { skleníkových plynů }\end{array}$ & $\begin{array}{l}\text { tun. Ekv. } \\
\text { CO2/rok }\end{array}$ & 3783 & 2014 & 1830 & $\begin{array}{l}\mathrm{R} O \mathrm{O} \text { z MS } \\
\mathrm{OP}\end{array}$ & $-52 \%$ \\
\hline Návrh OP & \begin{tabular}{|l} 
Počet objektů \\
využívajících OzE
\end{tabular} & objekty & 0 & 2014 & 25 & $\begin{array}{l}\text { Žadatel/ } \\
\text { př́ijemce } \\
\text { z MS OP }\end{array}$ & \\
\hline Návrh OP ŽP & $\begin{array}{l}\text { Energeticky vztažná } \\
\text { plocha } \\
\text { zrenovovaných } \\
\text { budov }\end{array}$ & $\mathrm{m} 2$ & 0 & 2014 & 49800 & $\begin{array}{l}\text { Žadatel/ } \\
\text { př́ijemce } \\
\text { z MS OP }\end{array}$ & \\
\hline
\end{tabular}

\section{Stanovení kritérií pro výběr pilotních objektů}

Pro dosažení vize SMART Prague je nezbytné začít realizací pilotních projektů, které ukáží směr rozvoje veřejných budov na území hl. m. Prahy a budou mít vysoký potenciál demonstrovat možnosti úspor energií a př́nosy instalace inteligentních systémů vč. dopadů na kvalitu prostředí a spokojenost uživatelů. V materiálu „Inteligentní budovy v konceptu Smart Prague“ z listopadu 2013 byla identifikována níže uvedená kritéria:

\section{Budova ve vlastnictví hl. m. Prahy}

Vzhledem k přirozenému vlastnictví konceptu SMART Prague v rukou hl. $\mathrm{m}$. Prahy je záměrem udržet také koordinaci nad prípravou a realizací pilotních projektů inteligentních budov. Toto kritérium je eliminační (ANO/NE).

\section{Zajištěná spolupráce s akademickým prostředním}

Vzhledem $\mathrm{k}$ faktu, že koncept inteligentních budov je do značné míry stále vysoce inovativní obor, je žádoucí do prípravy a realizace pilotních projektů zapojit také akademickou sféru. Tímto bude dosaženo synergií v souladu s konceptem "triple helix“, to je spolupráce mezi veřejnou správou (vlastník projektu), akademickou sférou (spoluautor projektu) a průmyslem (dodavatel projektu).

\section{Vysoký podíl fluktuace osob (značné výkyvy ve využití budovy)}

Vysoká fluktuace osob využívajících budovy klade velké nároky na řízení energetiky dané budovy, ale také například řízení výměny vzduchu. Sledovány a hodnoceny jsou především směnné provozy, kdy přes pracovní dobu je budovy využívána plně a mimo pracovní dobu se prakticky vylidňuje. Balancování těchto změn ve využití kapacity budovy přináší vysoký potenciál úspor.

\section{Skupiny budov $\mathbf{v}$ bezprostředním sousedství}

Toto kritérium do značné míry souvisí s předchozím bodem, nebot' de-facto řeší podobný problém v balancování využití daných budov $v$ čase. Vysoce jsou hodnoceny typy nemovitostí, které jsou vzhledem ke svému účelu často budovány jako skupiny budov, nebo je u nich pravděpodobné očekávat, že se jako skupina budov vyskytovat mohou.

\section{Vysoký potenciál úspor}

Pro výběr mezi pilotní projekty jsou vybírány pouze takové budovy, které z existujících informací z pasportu budovy ukazují na velké nedostatky z hlediska energetické náročnosti. 


\section{Vysoký potenciál přenosu zkušeností do dalších budov („referenční budova“)}

Toto kritérium si klade za cíl v rámci inteligentních budov a konceptu SMART Prague zapojit takové pilotní projekty, které mají vysoký potenciál přenosu do obdobných budov s podobnými obecnými stavebními a funkčními charakteristikami. Toto hodnocení odpovídá počtu budov ve stejné kategorii v rámci všech budov ve vlastnictví hl. $\mathrm{m}$. Prahy, přičemž největší bodové hodnocení mají budovy $\mathrm{s}$ největším počtem výskytu a vice versa.

\section{Logická návaznost na další opatření Smart Prague (a rozšířená až na 6 kritérií dle Vídeňské technické univerzity)}

Jednotícím konceptem pro pilotní projekty v oblasti inteligentních budov je koncept Smart Prague, vycházející z filosofie Smart City. Proto je potřeba zhodnotit prínos daného projektu pro pilíře SMART Infrastructure, SMART Specialization a SMART Creativity a také na rozšířený obecný koncept Smart City dle některých kritérií definovaných Vídeňskou technickou univerzitou, tj. Smart Economy, Smart Mobility, Smart Environment, Smart People, Smart Living, Smart Governance. (Tencar, Zadina, 2013)

Na základě vícekriteriálního hodnocení byly vybrány následující budovy vhodné pro implementaci prvků inteligentních budov.

Tab 2: Školy (primární a sekundární vzdělávání)

\begin{tabular}{|l|l|l|l|}
\hline Název & Ulice, č. p. / evid. č. & PSČ & Místo \\
\hline Střední průmyslová škola, Na Třebešíně & Na Třebešíně 2299/69 & 10800 & Praha 10 \\
\hline $\begin{array}{l}\text { Domov mládeže a školní jídelna Lovosická } \\
\text { Gy }\end{array}$ & Lovosická 439/42 & 19000 & Praha 9 \\
\hline Gymnázium Českolipská 373 & Českolipská 373/29 & 19000 & Praha 9 \\
\hline Gymnázium Na Vítězné pláni & Na Vítězné pláni 1160/1 & 14087 & Praha 4 \\
\hline $\begin{array}{l}\text { SŠ, ZŠ a MŠ pro sluchově postižené } \\
\text { Výmolova } 169\end{array}$ & Výmolova 169 & 15000 & Praha 5 \\
\hline ZŠ Vokovice Praha 6 & & 16000 & Praha 6 \\
\hline ZUŠ Taussigova, Praha 8 & Vokovická 32/3 & 18200 & Praha 8 \\
\hline SOU potravinářské Písnice & Taussigova 1150/2 & 14200 & Praha 4 \\
\hline
\end{tabular}

Tab 3: Budovy se službami sociální péče (Domovy pro seniory, ústavy)

\begin{tabular}{|l|l|l|l|}
\hline Název & Ulice, č. p. / evid. č. & PSČ & Místo \\
\hline Domov seniorů Elišky Purkyňové & Šolínova 513/3 & 16900 & Praha 6 \\
\cline { 2 - 4 } & Thákurova 12 & 16900 & Praha 6 \\
\hline Domov pro seniory Ďáblice & Kubíkova 1698/11 & 18200 & Praha 8 \\
\hline Domov pro seniory Chodov & Donovalská 2222 & 14900 & Praha 4 \\
\hline Domov pro seniory Zahradní Město & Sněženková 2973/8 & 10600 & Praha 10 \\
\hline
\end{tabular}




\begin{tabular}{|c|c|c|c|}
\hline Domov pro seniory Háje & K Milíčovu 734/1 & 14900 & Praha 4 \\
\hline \multirow[t]{5}{*}{ Jedličkův ústav } & V Pevnosti 13/4 & 12841 & Praha 2 \\
\hline & $\begin{array}{l}\text { Na Pankráci 13/479 - domov } \\
\text { mládeže }\end{array}$ & 14000 & Praha 4 \\
\hline & $\begin{array}{l}\text { Na Topolce 1/1350 - domov } \\
\text { mládeže }\end{array}$ & 14000 & Praha 4 \\
\hline & $\begin{array}{l}\text { Na Topolce } 1 \mathrm{~A} / 1713+ \\
\text { 1B/1714 - RH pavilon }\end{array}$ & 14000 & Praha 4 \\
\hline & $\begin{array}{l}\text { U Jedličkova ústavu 2/1349 - } \\
\text { Školy a rehab. Bazén }\end{array}$ & 14000 & Praha 4 \\
\hline
\end{tabular}

\section{Analýza současného stavu}

Pro všechny budovy byly zpracovány energetické audity, avšak již v letech 2003 až 2004 . Od té doby se technický stav budov již dost značně lišil a bylo nutné do analýzy zahrnout již provedená úsporná opatření. Na většině budov již byla vyměněna okna, někde bylo provedeno zateplení apod., avšak energetické audity nebyly aktualizovány.

Pro potřeby zpracování a hodnocení pilotního projektu byly analyzovány základní technické parametry a současné spotřeby energií.

Tab 5: Technické parametry vybraných objektů

\begin{tabular}{|c|c|c|c|c|c|c|c|c|c|}
\hline \multicolumn{10}{|c|}{ Popis objektu } \\
\hline Objekt & Adresa & \begin{tabular}{|c|} 
Obestavěný prostor \\
{$[\mathrm{m} 3]$}
\end{tabular} & $\begin{array}{c}\text { Vnitřní objem budovy } \\
{[\mathrm{m} 3]}\end{array}$ & \begin{tabular}{|c|} 
Vztažná plocha \\
[m2]
\end{tabular} & \begin{tabular}{|c|}
$\begin{array}{c}\text { Plocha stěn } \\
\text { [m2] }\end{array}$ \\
\end{tabular} & Plocha oken [m2] & $\begin{array}{c}\text { Šikmá střecha } \\
{[\mathrm{m} 2]}\end{array}$ & \begin{tabular}{|c|} 
Plochá střecha \\
[m2]
\end{tabular} & $\begin{array}{c}\text { Plocha podlah } \\
\text { [m2] }\end{array}$ \\
\hline Gymnázium & Na vítězné pláni 1160, Praha 4 & \begin{tabular}{|r|}
27970,0 \\
\end{tabular} & 22376,0 & \begin{tabular}{ll|}
7077,0 \\
\end{tabular} & 2679,0 & 1049,0 & - & 1554,0 & 6240,0 \\
\hline Domov pro seniory Praha 4 - Háje & K Miličovovu 734/1, Praha 4 & 39117,0 & 36987,0 & 10741,0 & 5575,0 & 1748,0 & 3218,0 & 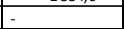 & \\
\hline Domov pro seniory Praha 4- Chodov & Donovalská 2222, Praha 4 & 37153,0 & 33852,0 & 5579,0 & 7649,2 & 2280,9 & 3250,6 & & \\
\hline Středni odborné učiliště potravinařské & Libušská 320/111 & 7333,0 & 6458,0 & 2246,0 & 1907,0 & 679,8 & 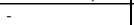 & 1123,0 & \\
\hline Zక̌ Vokovická & Vokovická 32/3, Praha 6 & 16445,0 & 10855,0 & 3403,0 & 2679,0 & 550,0 & - & 1802,0 & 1802,0 \\
\hline Spec. škola Výmolová & Výmolová 169 , Praha 5 & 20948,0 & 13616,0 & 4645,0 & 3980,0 & 717,0 & 1026,0 & 00,0 & 979,0 \\
\hline Jedličkưv ústav, Stará budova & V pevnosti 4, Praha 4 & 11956,0 & 7771,0 & 3060,0 & 2473,0 & 373,0 & 909,0 & & 942,0 \\
\hline Jedličkův ústav, Nová šk. + bazén & U Jedličkova ústavu 2, Praha 4 & 19853,0 & 13473,0 & 5225,0 & 2580,0 & 701,0 & - & 1508,0 & 1548,0 \\
\hline Útvar rozvoje hlavniho města Prahy & VYŠËEHADSKÁ 51, 55, 57, Praha 2 & 34400,4 & 27520,3 & 8200,0 & 13002,5 & & & 2779,0 & \\
\hline \begin{tabular}{|l|} 
DS Sněěenková \\
\end{tabular} & Sněženková 8, Praha 10 & 21879,0 & 16409,3 & 10375,0 & 2584,0 & 1343,3 & - & 2075,0 & 2075,0 \\
\hline DM Lovosická & Lovosická 42, Praha 9 & 18678,0 & 14008,5 & 7154,0 & 4159,4 & 2038,1 & - & 1148,0 & 1148,0 \\
\hline Gymnázium Českolipská & Českolipská 373, Praha 9 & 38754,0 & 29065,5 & 7896,0 & 6252,0 & 1728,0 & - & 3948,0 & 3948,0 \\
\hline ZUŠ Taussigova & \begin{tabular}{|l|} 
Taussigova 1150, Praha 8 \\
\end{tabular} & 11767,0 & 8825,3 & 3412,0 & 2466,0 & 988,0 & - & 914,1 & 914,1 \\
\hline \begin{tabular}{|l|} 
DS Rektorská \\
\end{tabular} & Rektorská 577/5, Praha 10 & 36396,0 & 27297,0 & 9138,0 & 9082,0 & 522,6 & - & 540,0 & 540,0 \\
\hline DS Kobylisy & Mirovická 1027/19, P8 & 32299,7 & 24224,8 & 9787,9 & 3732,1 & 837,8 & 2524,0 & $0+0,0$ & 2524,0 \\
\hline Jedličkův ústav, TOP & U Na Topolce 1, Praha 4 & 15377,0 & 10948,0 & 4139,0 & 2390,0 & 422,0 & 1177,0 & & 1077,0 \\
\hline Jedličkův ústav, TAP & Na Pankráci 13, Praha 4 & 5387,0 & 3771,0 & 1688,0 & 844,0 & 123,0 & 298,0 & & 280,0 \\
\hline Domov důchodcú Šolínova & Šolinova $1,3,5$, , Praha 6 & 18872,0 & 12267,0 & 5774,0 & 3347,0 & 625,0 & 1133,0 & & 1054,0 \\
\hline Domov důchodců Thákurova & Thákurova 8,10,12, Praha 6 & 14600,0 & 9490,0 & 3520,0 & 2451,0 & 427,0 & 954,0 & & 879,0 \\
\hline \multirow[t]{3}{*}{ SPŠ Na Třebešsině } & $\mathrm{Na}$ Třebešíně 2299, P10 & 123995,0 & 92996,3 & 20953,0 & 14204,3 & 3981,9 & & 9093,0 & 9093,0 \\
\hline & & & & & & & & & \\
\hline & & 553180 & 422211 & 134013 & 94037 & 21135 & 14490 & 26484 & 35043 \\
\hline
\end{tabular}

Energeticky vztažná plocha trojnásobně převyšuje požadavek na indikátor OP. 
Tab 6: Současné energetické náročnosti objektů vybraných do pilotního projektu

\begin{tabular}{|c|c|c|c|c|c|c|c|c|c|c|c|c|c|c|c|c|}
\hline & & Popis objektu & \multicolumn{14}{|c|}{ Stávajicí stav } \\
\hline$P \ddot{c}$ & objekt & Adresa & $\begin{array}{r}\text { Potréeba vytápeñi } \\
{[G]}\end{array}$ & Spotřeba vytápěni & $\begin{array}{c}\text { Ener } \\
\text { gon } \\
\text { osit } \\
\text { osit } \\
\text { el| } \\
\text { yytá } \\
\text { pěni }\end{array}$ & \begin{tabular}{|r|} 
Spotřeba větráni \\
$[G]]$ \\
{$[G]$}
\end{tabular} & \begin{tabular}{|c|} 
Ener \\
gono \\
sitel \\
vetrtr \\
anni
\end{tabular} & $\begin{array}{c}\text { Spotřeba } \\
\text { TUV [G] }\end{array}$ & \begin{tabular}{|r|} 
Ener \\
gon \\
osit \\
el
\end{tabular} & $\begin{array}{r}\text { Spotřeba energie } \\
[G]]\end{array}$ & \begin{tabular}{|c} 
Ener \\
gono \\
sitel \\
TĆ
\end{tabular} & $\begin{array}{r}\text { Emise CO2 } \\
{[t / \text { rok }]}\end{array}$ & $\begin{array}{c}\text { Součet Emise } \\
\cos [t / \text { rokk] }\end{array}$ & $\begin{array}{r}\text { Neobnov. prim. en. } \\
{[[G]}\end{array}$ & Součet [G] & $\left|\begin{array}{r}\text { Primárni } \\
\text { energie [MWh] }\end{array}\right|$ \\
\hline 1 & Gymnázium & Na vitěznné pláni 1160, Praha 4 & 2432,48 & 2644,00 & 0 & 31,06 & 3,00 & 579,00 & 1,10 & $\frac{3223,00}{33,06}$ & $\begin{array}{ll}1,10 \\
300\end{array}$ & $\begin{aligned} 180,85 \\
820 \\
\end{aligned}$ & 189,04 & $\begin{aligned} 3545,30 \\
93,18 \\
\end{aligned}$ & 3638,48 & 1011 \\
\hline 2 & Domov pro seniory Praha 4- Hajje & K Milič̈ovu 734/1, Praha 4 & 3760,22 & 4087,20 & 01,10 & 59,80 & 3,00 & 847,50 & 1,10 & $\begin{array}{r}3934,70 \\
59,80\end{array}$ & $\begin{array}{l}3,00 \\
3,00 \\
300\end{array}$ & $\begin{array}{r}, 276,99 \\
27,78 \\
15\end{array}$ & 292,67 & $\begin{aligned} 539,18,7 \\
548,40 \\
1970\end{aligned}$ & 5607,57 & 1558 \\
\hline 3 & Domov pro seniory Praha 4-Chodov & Donovalská 2222, Praha 4 & $\begin{array}{l}4486,47 \\
\end{array}$ & 4876,60 & 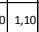 & 71,34 & 3,00 & 557,05 & 1,10 & \begin{tabular}{r|r|r|}
5433,55 \\
7134
\end{tabular} & \begin{tabular}{|l|l|}
1,10 \\
3,00
\end{tabular} & $\begin{array}{l}304,89 \\
1882 \\
\end{array}$ & 323,71 & $\begin{array}{l}5977,02 \\
2401\end{array}$ & 6191,02 & 1720 \\
\hline 4 & 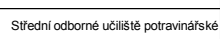 & Libušská 320/111 & 2094,13 & 2276,23 & \begin{tabular}{|l|l|}
3 & 1,10 \\
\end{tabular} & 22,29 & 3,00 & 185,47 & 1,10 & 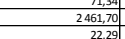 & \begin{tabular}{|l|}
3,00 \\
1,100 \\
300
\end{tabular} & $\begin{array}{r}138,13 \\
588 \\
58 .\end{array}$ & 144,01 & $\begin{array}{rl}274,01 & 2707,87 \\
66,87\end{array}$ & 2774,74 & 771 \\
\hline 5 & zš Vokovická & Vokovická 32/3, Praha 6 & 1603,48 & 2511,35 & 51,10 & 0,00 & 3,00 & 112,65 & 51,10 & 2624,00 & 1,10 & $\begin{aligned} 147,24 \\
0,261\end{aligned}$ & 244,87 & 2886,40 & 3996,40 & 1110 \\
\hline 6 & Spec, škola Výmolová & Výmoloví 169 , Praha 5 & 1649,38 & 2525,83 & \begin{tabular}{ll|l}
3 & 1,10 \\
\end{tabular} & 0,00 & 3,00 & 77,41 & 1,10 & $\begin{array}{r}2603,00 \\
33400\end{array}$ & \begin{tabular}{|l|l|}
1,10 \\
3,00
\end{tabular} & $\begin{aligned} 146,06 \\
88,4 \\
\end{aligned}$ & 234,20 & 2863,30 & 3865,30 & 1074 \\
\hline 7 & Jedličḱưv ústav, Stará budova & $\checkmark$ pevnosti 4, Praha 4 & 1366,74 & 2140,56 & 61,10 & 0,00 & 3,00 & 118,29 & 1,10 & 2198,00 & 1,10 & $\begin{aligned} 123,33 \\
65,44\end{aligned}$ & ${ }_{188,78}$ & 247,80 & 3161,80 & 878 \\
\hline 8 & Jedlï̌kivi ústav, Novó śsk. + bazén & UJedli ǐkova ústavu 2, Praha 4 & 2664,46 & 4195,68 & 81,10 & 179,35 & 3,00 & 95.95 & 51.10 & $\begin{array}{lll}4292,000 \\
4290\end{array}$ & 1,10 & 240,83 & $382.80-5,-5,2$ & 4721,20 & 6335200 & 1760 \\
\hline g] & & 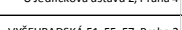 & & $-40,0,0$ & & & & 然 & tite & 538,00 & 3,00 & \begin{tabular}{|c|c|}
141,97 \\
55773
\end{tabular} & & $\begin{array}{ll}1614,00 \\
651100\end{array}$ & & \\
\hline & Utvar rozvoje hlavniho mésta Prahy & VYSEERRADSKA 51, 55, 57, Praha 2 & 7182,55 & 7900,80 & $0 \mid 1,10$ & 2170,33 & 3,00 & 1795,64 & (4) $1,10 \mid$ & 8978,18 & 1,10 & 503,78 & $1076,50 \mid$ & 9876,00 & 16387,00 & 4552 \\
\hline 10 & DS Snẽěnnková & Snëěenkoví 8, Praha 10 & 2141,17 & 2951,06 & 61,10 & 0,00 & 3,00 & 461,63 & 31,10 & $\begin{array}{ll}3412,70 \\
248,58\end{array}$ & $\frac{1,10}{300}$ & $\frac{191,49}{65.50}$ & 257,09 & $\begin{array}{ll}3753,70 \\
775,74 \\
\end{array}$ & 4499,44 & 1250 \\
\hline${ }_{11}$ & DM Lovosická & Lovosická 42, Praha 9 & 1114,67 & 1536,29 & 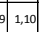 & 0,00 & 3,00 & 461,63 & 1,10 & $\begin{array}{c}1997,93 \\
17024 \\
\end{array}$ & \begin{tabular}{|l|}
1,10 \\
3,00
\end{tabular} & $\frac{112,11}{44,92}$ & 157,03 & $\begin{aligned} 2197,72 \\
51727 \\
\end{aligned}$ & 2708,44 & 752 \\
\hline 12 & Gymnázium Českolipská & Českolipská 373, Praha 9 & 1834,42 & 2528,29 & \begin{tabular}{l|l}
9,10 \\
9.
\end{tabular} & 0,00 & 3,00 & 230,63 & 1,10 & 2758,91 & \begin{tabular}{|l|l|l|l|}
1,10 \\
\end{tabular} & $\frac{154,81}{155}$ & 161,33 & 3034,80 & 3108,96 & 864 \\
\hline 13 & zuš Taussigova & Taussigova 1150, Praha 8 & 639,96 & 882,02 & 21,10 & 69,72 & 3,00 & 48,87 & 1,10 & $\begin{array}{l}951,74 \\
52989\end{array}$ & 1,10 & $\begin{array}{l}53,340 \\
68.58 \\
8\end{array}$ & 121,99 & $\begin{array}{l}1046,92 \\
765404\end{array}$ & \begin{tabular}{ll|l}
1833,36 \\
\end{tabular} & 509 \\
\hline 14 & DS Rektorská & Rektorská $577 / 5$, Praha 10 & 1478,66 & 2045,15 & $5 \mid \begin{array}{l}1,10 \\
|c| c|c|\end{array}$ & 59,16 & 3,00 & 1210,34 & 4,10 & $\begin{array}{lll}358,1,04 \\
51704\end{array}$ & $\begin{array}{l}3,10 \\
1,10 \\
\end{array}$ & 200,94 & 386,355 & 3581,04 & 4239,74 & 1178 \\
\hline 15 & DS Kobylisy & Mirovická 1027/19, P8 & 1912,24 & 2691,03 & 31,10 & 0,00 & 3,00 & 491,73 & 300 & 3582,75 & \begin{tabular}{|l|l|}
$, 1,10$ \\
\end{tabular} & $\begin{array}{l}20101,03 \\
201,03 \\
\end{array}$ & 255,48 & $\begin{array}{ll}3939,03 \\
3941,03 \\
\end{array}$ & 5233.55 & 1454 \\
\hline & & & & & & & & & & 964,21 & & 254,44 & & 1292,62 & 5253,05 & 1454 \\
\hline 16 & Jedličkīivústav, TOP & U Na Topolce 1, Praha 4 & 1133,04 & 1679,15 & $5,1,10$ & 0,00 & 3,00 & 128,74 & 4,00 & $\frac{1679,15}{16080,0}$ & $\begin{array}{l}1,10 \\
3,00 \\
\end{array}$ & $\frac{94,22}{424,3}$ & 518,57 & $\frac{1847,07}{482424}$ & 6671,31 & 1853 \\
\hline 17 & Jedličkiviv ústav, TAP & Na Pankráci 13, Praha 4 & 574,35 & 879,55 & 51,10 & 0,00 & 3,00 & 54,90 & 3,00 & $\begin{array}{ll}915,49 \\
4700\end{array}$ & \begin{tabular}{|l|l|}
1,10 \\
300
\end{tabular} & $\begin{array}{c}51,37 \\
12561 \\
\end{array}$ & ${ }_{176,98}$ & $\begin{array}{ll}1007,04 \\
142800\end{array}$ & 2435,04 & 676 \\
\hline 18 & Domov düchodcú šolinova & Šolinova 1,3,5, Praha 6 & 2247,88 & 3098,12 & 1,00 & 0,00 & 3,00 & 922,29 & 1,10 & $\begin{array}{r}96,00 \\
302,29 \\
308,12 \\
\end{array}$ & \begin{tabular}{|l|}
3,00 \\
1,10 \\
1,00 \\
\end{tabular} & $\begin{array}{r}125,61,75 \\
817,56 \\
\end{array}$ & 1270,93 & $\begin{array}{l}1482,00 \\
\begin{array}{l}104,52 \\
3098,12\end{array}\end{array}$ & 8678,46 & 2411 \\
\hline & & & & & & & & & & 1521,94 & 3,00 & $\begin{aligned} 401,62 \\
401,5\end{aligned}$ & & 4565,82 & & \\
\hline 19 & Domov dúchodccu Thákurova & Thakurovova 8,10,12, Praha 6 & 1489,211 & 2025,50 & 0 & 0,00 & $3,00 \mid$ & 62649 & 93000 & $\begin{array}{ll}0.000 \\
2678,90\end{array}$ & 0,00 & $\frac{0,00}{70096}$ & $951,69[7>20$ & $\begin{aligned} 0,000 \\
2678999\end{aligned}$ & 546128 & 1517 \\
\hline & & & & & & & & & sol & 927,43 & 3 & 24,74 & & 2782,29 & & \\
\hline 20 & SPŠ Na Třebešině & Na Tréebešnine 2299, p10 & 5613,00 & 7736,00 & 0 & 0,00 & 3,00 & 678,00 & 3,00 & 8415,00 & $\frac{1,10}{300}$ & $\begin{array}{lll}472,18 \\
638372\end{array}$ & 1155,65 & 9256,00 & 17027,00 & 4730 \\
\hline & & & & & & & & & & & & & & & & \\
\hline & Celkem & & 47448,52 & 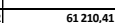 & & $2663.055,20>0$ & & 9684,211 & & 84080,85 & & 8689,68 & $8689,68 \mathrm{~F}$ & 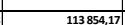 & 7) 1113854,17 & 31626 \\
\hline
\end{tabular}

Kumulovaná spotřeba primárních energií je u těchto 20 areálů na hodnotě $31600 \mathrm{MWh}$. Tato hodnota je nižší o přibližně $2000 \mathrm{MWh}$ oproti indikátoru, jelikož na části budov již byly provedeny dílčí opatření ve formě zateplení a výměny oken. Žádná z uvedených budov ovšem nesplňovala požadavky na inteligentní budovu a některá opatření byla nedostatečná. Jednalo se ve většině př́padů o nedostatečnou tloušt́ku zateplení a okna s vysokým prostupem tepla.

\section{Transformace objektů}

Na všechny objekty byla implementována následující opatření vedoucí ke sní̌ení spotřeby primární energie a emisí $\mathrm{CO}_{2}$. Veškerá opatření jsou reprezentativní s ohledem na motivaci a stimulaci uživatelů a dalších osob k šetrnému zacházení s energiemi, vodou a odpady. Snížení spotřeby energie na základě provedených opatření povede kvytvoření budovy stéměř nulovou spotřebou energie. (Karásek, Zahradník, 2013)

\section{Zateplení obálky budovy}

Na základě zjištěných nedostatečných zateplení budov, byla navrhována dodatečná kompletní zateplení. Bylo tím dosaženo minimalizace tepelných ztrát objektu.

U většiny objektů bylo navrženo kompletní zateplení budovy EPS 70 NEO (Grey Wall) tl. $250 \mathrm{~mm}$. U objektů nedostatečně zateplených navrženo dodatečné zateplení minimálně na celkovou tloušt́tku 250 $\mathrm{mm}$. V prípadě jiných požadavků, především z hlediska požární ochrany, Ize EPS nahradit např. minerální vatou.

\section{Výměna výplní otvorů}

Zasklení výplní otvorů bude provedeno skly optimalizovanými pro daný účel užívání, především s ohledem na solární faktor g. Pro všechny aplikace pak s co nejnižší hodnotou součinitele prostupu tepla Ug. U všech otevíratelných oken bude instalováno čidlo otevření, které v případě zastaví přívod vzduchu z rekuperační jednotky a uzavře topení. Toto čidlo je zároveň bezpečnostním prvkem proti vniknutí do objektu v př́ípadě opomenutí okno zavřít. 


\section{Instalace nuceného větrání - rekuperace}

U všech objektů byl navržen systém nuceného větrání s rekuperací. Nucené větrání zajišttuje příznivé vnitřní prostředí. Rekuperace = zpětné získávání tepla. Přiváděný venkovní čerstvý vzduch prochází přes rekuperační výměník uvnitř vzduchotechnické jednotky, do kterého z druhé strany vstupuje teplý odpadní vzduch z objektu. Obě vzdušniny jsou od sebe dokonale odděleny soustavou kanálků, aby nedocházelo ke zpětnému průniku pachů z odváděného do přívodního vzduchu.

\section{Obnovitelné zdroje energií}

U všech objektů je navrženo využití obnovitelných zdrojů energií. Jedná se především o solárnětermické systémy na ohřev TV a tepelná čerpadla s vysokým topným faktorem (vyšší než 3).

\section{Energeticky úsporné osvětlení}

Energeticky úsporného osvětlení, které je vhodné pro školy a tedy splňuje přísné podmínky na osvícení pracovního prostoru dané normami, je možné dosáhnout na základě digitálně ovládaných světel s jasovým čidlem, které koriguje světelný tok ze stropních svítidel s ohledem na přirozené venkovní světlo.

Ovládání svítidel je řešeno digitálním signálem, každé svítidlo Ize řídit samostatně. Osvětlovací soustavu je možno rozdělit do skupin a naprogramovat scény pro typické situace $v$ učebně. Jedním stisknutím tlačítka je tak možno např. 1 . řadu rozsvítit na $10 \%$, prostřední řadu na $40 \%$ a 3 . řadu na 90 \% svítivosti. Jinou variantou může být scéna osvětlení pro videoprezentace.

V objektech Domovů pro seniory nejsou tak vysoké požadavky na osvětlení a je vhodné osadit LED světly s manuálním ovládáním. Tím bude dosaženo požadovaného umělého osvětlení a minimalizována spotřeba elektrické energie.

\section{Stínění objektů}

Na vybraných objektech bude instalováno vnější stínění oken omezující přehřívání interiéru a zvyšující spotřebu energií nutností chlazení. Dle typu objektu budou instalovány elektronické vnější žaluzie nebo vnější slunolamy.

\section{Využití deštóvé vody}

Do všech objektů budou instalovány nádrže na zachytávání a využití deštové vody. Úspora vody pomocí retenční nádrže na zachytávání deštové vody je již známá. Retenční nádrž zachycuje deštové srážky ze zpevněných ploch a střech, které jsou následně využity na další účely (např. závlahová voda, zásoba vody pro protipožární účely prostřednictvím požární nádrže) nebo jsou postupně odpouštěny do kanalizace, čímž nezatěžují okolní prostředí a kanalizaci. (Konášová, 2016)

\section{Úsporné baterie a nakládání s pitnou vodou}

Do všech objektů budou instalovány baterie, případně perlátory a spotřebiče omezující spotřebu pitné vody.

\section{Nakládání s odpady}

$\checkmark$ rámci budov budou umístěny koše na tříděný odpad. U budov budou instalovány kontejnery na tříděný odpad.

\section{Integrace Building Management System}

$\checkmark$ procesu BMS se sledují a řídí operační systémy $v$ rámci budovy (například systémy vytápění, klimatizace, ventilace či osvětlení, bezpečnosti, požární ochrany apod.). Jedná se o tedy řídicí proces, který působí na řizenou soustavu a ovládá ji pro optimální a bezpečné zajištění energetických potřeb s minimální zátěží životního prostředí. Management hospodaření s energiemi pak šetří nejvíce nákladů 
a je nejefektivnější ve velkých provozních budovách jako jsou právě školy, domovy pro seniory a administrativní budovy.

Veškeré procesy BMS budou zavedeny na základě norem, např. ČSN EN 16001 Systémy managementu hospodaření s energií

Automatizace procesů řízení bude získávat data z vnitřních čidel (teplota, vlhkost, obsah $\mathrm{CO}_{2}$, osvícení, senzory otevření oken, apod.), vnějších čidel (teplota, směr větru, osvícení, atd.). Nedílnou součástí automatizace budou předpovědi počasí z ČHMÚ, na které bude systém s předstihem reagovat. Tzn. přirození využití ochlazení interiéru budovy $v$ letním období $v$ nočních hodinách, zvýšení/snížení výkonu topné/chladící soustavy apod.

Do automatického řízení bude možné kdykoliv manuálně zasáhnout v př́padě změny aktuálního využití vnitřního prostoru oproti standartnímu provozu.

\section{Bezpečnost}

Na systémy automatizace procesu budou napojeny systémy zajištúující bezpečnost. Nejedná se pouze o kamerový systém a čidla otevření oken, ale především prvky požární ochrany. Systémy včasného varování budou schopny minimalizovat škody v případě nenadálých událostí.

\section{Projektová príprava}

Projektová př́íprava jednotlivých projektů je nedílnou součástí př́ípravy úsporných opatření. Ve spolupráci s odborníky (Odborná rada pro BIM) budou připraveny projekty včetně implementace BIM (Building Information Modeling). BIM vedle digitálního modelu projektu vytváří i velké množství parametrů. Mezi parametry se řadí napríklad čas, cena, prostor a další informace. Jedná se o takzvané vícerozměrné modelování. Jedním z hlavních přínosů vícerozměrného modelování je kategorie 5D (práce s prvky a jejich cenami). (Matějka, 2016) Tato kategorie má patřičný význam v celém životním cyklu stavby. $V$ předinvestiční a investiční fázi se musí klást velký důraz na tvorbu kvalitních stavebních rozpočtů a kalkulací, které ovlivňují realizaci projektu. Na straně druhé je nutné se ohlížet na náklady v provozní fázi. Snižení provozních nákladů Ize docílit kvalitou stavebních prací a dodržením technologických postupů při výstavbě, ale hlavně zavedením systému BIM, který přináší vyšší nároky na zpracování projektu. Takto zpracovaný projekt je možné sdílet mezi jednotlivými zpracovateli technologických částí a doplňovat informace v průběhu realizace i provozování objektu. Díky tomu dojde ke snižení nákladů na další možné rekonstrukce a stavební úpravy, jelikož nebude nutné zpracovávat nový projekt. Jeho aktuální verze bude kdykoliv přístupná z centrálního uložiště. (Matějka, TOMEK, 2014)

\section{Certifikace budov}

Hodnocení komplexní kvality budov z hlediska širokého spektra kritérií udržitelnosti se v řadě zemí stává běžnou součástí projektového a realizačního procesu výstavby budovy. Rủzní účastníci tohoto procesu mají rozdílnou motivaci pro využití výsledků hodnocení. Záměrem státní správy je úspora strategických surovinových zdrojů a snižování ekologické zátěže a uživatelé očekávají zvýšení kvality vnitřního prostředí budovy i jejího okolí a to vše při snižení celkových nákladů a dopadů na životní prostředí. (DOBIÁŠ, J., MACEK, D., 2014)

Budovy před a po realizaci úsporných opatření budou hodnoceny a certifikovány lokalizovanou metodikou komplexní certifikace budov, která reflektuje národní standardy, resp. specifika České republiky. Tímto bude garantováno kvalitní provedení realizovaných opatření, které přinese nejen úsporu spotřeby energií, minimalizaci dopadu budovy na životní prostředí, zlepšení kvalitu vnitřního prostředí a využití certifikovaných materiálů.

Budovy budou certifikovány na základě tří hledisek:

- Environmentální kritéria (životní prostředí); 
- Sociální kritéria (neboli také sociálně-kulturní);

- Ekonomika a management

\section{Spolupráce vysokých škol}

Vzhledem $\mathrm{k}$ faktu, že koncept inteligentních budov je do značné míry stále vysoce inovativní obor, bude do př́pravy a realizace pilotních projektů zapojena také akademická sféra. Tímto bude dosaženo synergií v souladu s konceptem "triple helix", to je spolupráce mezi veřejnou správou (vlastník projektu), akademickou sférou (spoluautor projektu) a průmyslem (dodavatel projektu).

\section{LCC - Life Cycle Cost}

Metoda ekonomické analýzy, která hodnotí po určitý posuzovaný časový úsek všechny důležité náklady na budovu, náklady jejich systémů nebo komponentů v současné hodnotě (NPV - Net Present Value). (Heralová, 2014)

- Investiční náklady

- Provozní náklady a náklady na údržbu a opravy

- Náklady na periodické výměny

- Finanční kritéria (diskontní sazba [\%], míra růstu cen [\%], hodnocené časové období [roky]

\section{LCA - Life Cycle Assessment}

Posuzování životního cyklu (anglicky: Life Cycle Assessment, je metoda posuzování životního cyklu budovy z hlediska jeho působení na životní prostředí. $V$ úvahu bere procesy od těžby nerostných surovin přes dopravu, výrobu, užití až ke konečnému zpracování jako odpadu a zohledňuje energetické a surovinové náklady a dopad na životní prostředí pro každý z nich. Důležité jsou zejména emise do ovzduší, vody i půdy a spotřeba energie a materiálů.

Tab 7: Předpokládané investiční náklady

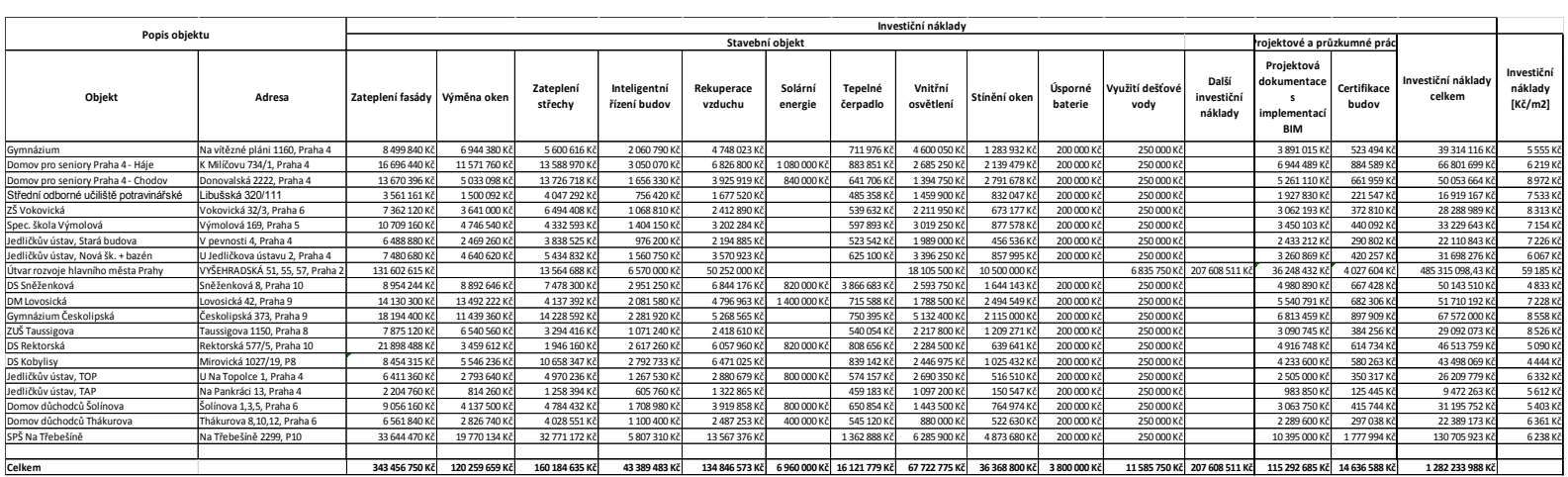

Pro všechny objekty vybrané do pilotního projektu byly určeny předpokládané náklady na realizaci úsporných opatření a implementaci systémů inteligentních budov. Výše uvedená tabulka shrnuje jednotlivé investiční náklady pro jednotlivé budovy.

Celkové předpokládané investiční náklady dosahují výše 1,28 mld. Kč. Při této investici dojde ke snižení spotřeby primární energie o více než 50 \% oproti stávajícímu stavu.

Nákladově významně vyčnívá soubor budov Útvaru rozvoje hlavního města Prahy. Tyto značně vysoké investiční náklady jsou způsobeny kompletní rekonstrukcí budovy, včetně vnitřních instalací a technologií. Bude nezbytné zasáhnout do nosných konstrukcí a měnit dispozice a vnitřní uspořádání. Je předpoklad, že budova po rekonstrukci bude splňovat požadavky lokalizované komplexní certifikace 
SBToolCZ Zlatý certifikát. Celkové investiční náklady jsou 485 mil. Kč, z toho 207 mil. Kč tvoří náklady na demolice a úpravy statiky a vnitřní dispozice.

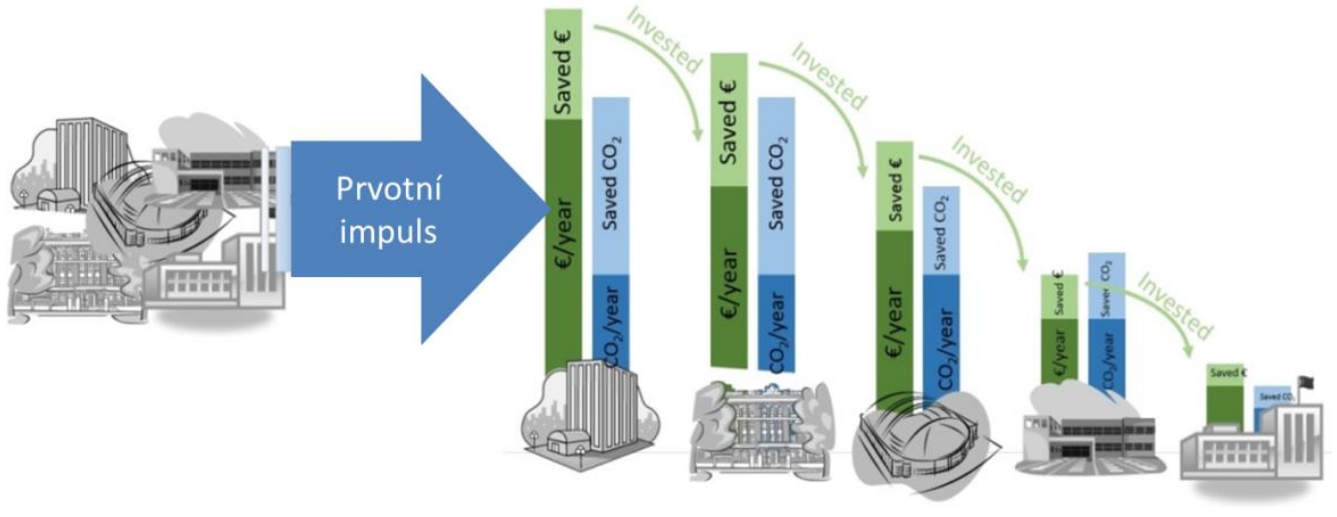

Figure 2: Schéma zavedení energetického managementu

Postupnou realizací transformace na inteligentní budovy od roku 2014 do roku 2023, dle předchozího diagramu dojde ke snížení spotřeby primární energie o 17 tis. MWh ročně. Kumulovaná úspora primární energie v letech 2014 až 2023 je přes 100 tis. MWh.

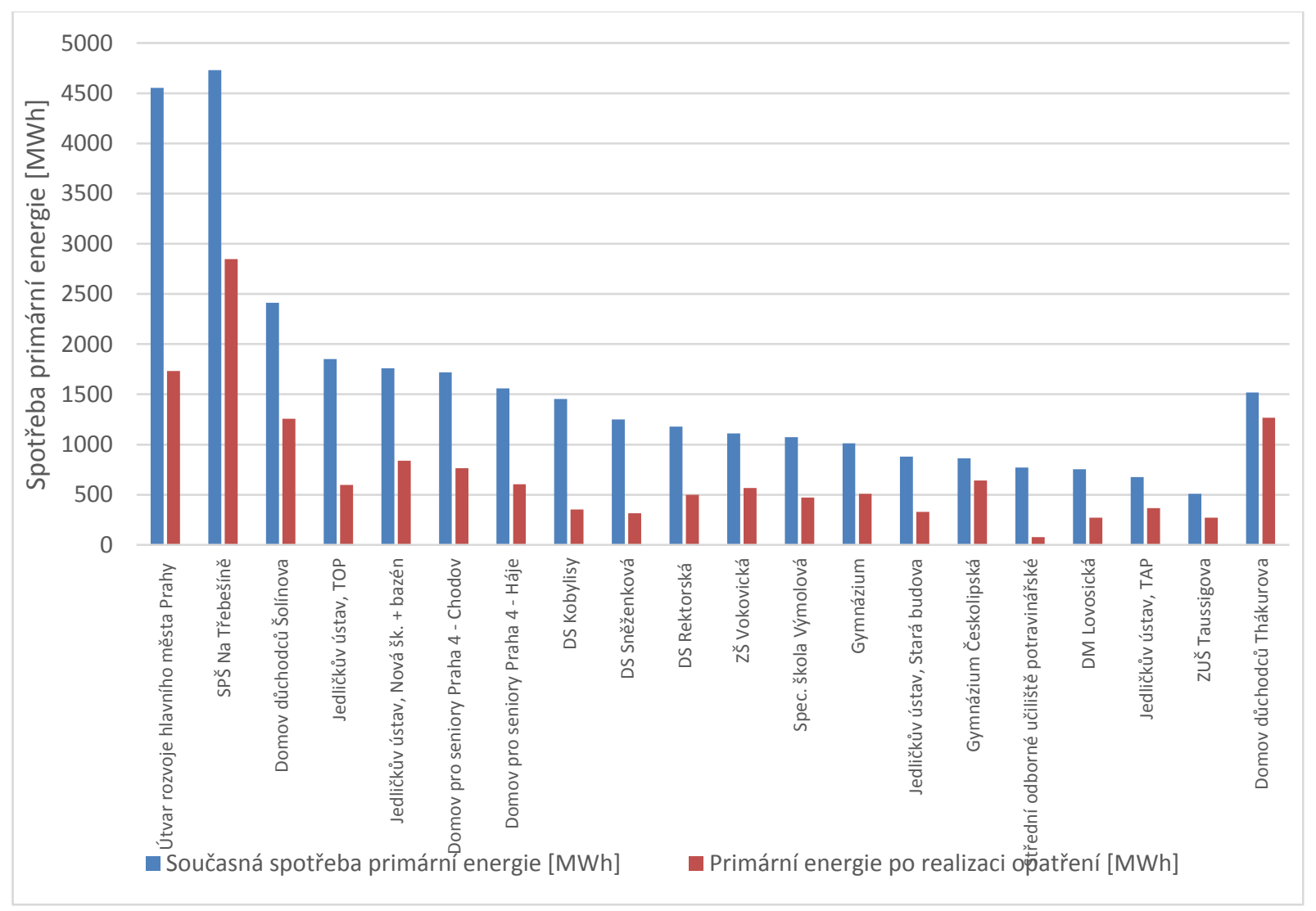

Figure 3: Pořadí doporučené realizace úsporných opatření

\section{Závěr}

Hlavní město Praha připravuje ambiciózní plán transformace objektů na nízkoenergetické inteligentní budovy. $V$ rámci tohoto pilotního projektu má být revitalizováno na 20 budov občanské vybavenosti v majetku města. Pro všechny budovy byl analyzován současný stav a navržena opatření vedoucí nejen $\mathrm{k}$ energetickým úsporám. Hlavní přidanou hodnotou má být osvěta obyvatel $\mathrm{v}$ environmentální oblasti a využití inteligentních prvků budov. 
Pro potřeby aktualizace Územní energetické koncepce byla zpracována „Analýza potenciálu transformace vybraných objektů $v$ majetku hlavního města Prahy na inteligentní budovy $v$ rámci konceptu Smart Prague, která v tomto článku byla představena.

$\mathrm{Na}$ tento pilotní projekt bude moci využít finančních prostředků alokovaných $v$ Operačním programu Praha - pól růstu v programovacím období 2014 - 2023. Předpokládané investiční náklady transformace dosahují výše 1,28 mld. Kč a předpokládá se $50 \%$ spolufinancování z fondů EU. Hlavní město Praha v současnosti pověřilo Institut plánování a rozvoje hl. $\mathrm{m}$. Prahy koordinací a př́pravou konceptu Smart City a bude spolupracovat s městy Manchesterem a Eindhovenem, od kterých bude získávat zkušenosti a následně implementovat.

Tento pilotní projekt bude sloužit nejen Hlavnímu městu Praze, ale i dalším městům, vysokým školám a výzkumným ústavům, ale i soukromým investorům, kteři projeví zájem o zkušenosti z realizace a provozování inteligentních budov. 


\section{References}

[1] Tencar, J.; Rohlena, M. et al. (2014), studie: Analýza potenciálu transformace vybraných objektů v majetku hlavního města Prahy na inteligentní budovy v rámci konceptu Smart Prague, Prague: Czech Technical University in Prague

[2] Tencar, J.; Zadina, (2013), Intelligent Buildings in the Concept of Smart Prague [Study], Prague, Czech Republic

[3] Giffinger, R., Fertner, C., Kramar, H., Kalasek, R., Pichler-Milanovic, N., Meijers, E. (2007): Smart cities Ranking of European medium-sized cities, http://www.smart-cities.eu , Vienna: Centre of Regional Science

[4] Pakt starostů a primátorů [online], European commision, [vid. 25. 4. 2014] Dostupné z: www.eumayors.eu

[5] Smart cities and comunnities [vid. 25. 4. 2014] Dostupné z: www.eu-smartcities.eu

[6] Český statistický úřad [online], ČsU, [vid. 25. 4. 2013], Dostupné z: www.czso.cz

[7] Eurostat [online], European commision, [vid. 25. 4. 2014], Dostupné z: epp.eurostat.ec.europa.eu

[8] CTIBOR, Tomáš. Praha rozhodla, jak dohnat západní metropole. StavbaWEB [online]. 2014, [cit. 25. 4. 2014]. Dostupné z: http://1url.cz/njp6

[9] Vonka, M.; Hájek, P.; Havlík, F.; Hodková, J.; Lupíšek, A.; et al.: (2011) The National Methodology for the Certification of Buildings in Terms of Sustainable Construction SBToolCZ. Prague: CTU in Prague

[10] Sinopoli, J.M. (2009), Smart Buildings Systems for Architects, Owners and Builders, ButterworthHeinemann, Burlington

[11] Quaschning, V. (2010), Obnovitelné zdroje energií, Grada, Praha

[12] KONÁŠOVÁ, Š. The efficiency of green roofs to mitigate urban heat island effect in Rio de Janeiro. In: Advances and Trends in Engineering Sciences and Technologies II: Proceedings of the 2nd International Conference on Engineering Sciences and Technologies, 29 June - 1 July 2016, High Tatras Mountains, Tatranské Matliare, Slovak Republic. 2nd International Conference on Engineering Sciences and Technologies. Tatranské Matliare, 29.06.2016 - 01.07.2016. Boca Raton: CRC Press. 2016, pp. 465-470. ISBN 9781138032248. Available from: https://www.crcpress.com/Advances-and-Trends-inEngineering-Sciences-and-Technologies-II-Proceedings/Ali-Platko/p/book/9781138032248

[13] MACEK, D. and DOBIÁŠ, J. Buildings renovation and maintenance in the public sector. Procedia Engineering. 2014, 2014(85), pp. 495-501. ISSN 1877-7058. Available from: http://www.sciencedirect.com/science/article/pii/S1877705814019286. https://doi.org/10.1016/j.proeng.2014.10.562

[14] KARÁSEK, J. and ZAHRADNÍK, Petr. Education for the On-site Workers towards to the Nearly Zero Energy Houses. In: HÁJEK, P., et al., eds. CESB 13 Central Europe towards Sustainable Building 2013. CESB 13 Central Europe towards Sustainable Building 2013. Praha, 26.06.2013 - 29.06.2013. Praha: GRADA PUBLISHING. 2013, ISBN 978-80-247-5018-7.

[15] MATĚJKA, P., et al. The Integration of BIM in Later Project Life Cycle Phases in Unprepared Environment from FM Perspective [online]. In: Procedia Engineering. Creative Construction Conference 2016. Budapest, 25.06.2016 - 28.06.2016. Amsterdam: Elsevier B.V.. 2016, pp. 550-557. vol. 164. ISSN 18777058. Available from: http://www.sciencedirect.com/science/article/pii/S1877705816339984. https://doi.org/10.1016/j.proeng.2016.11.657

[16] MATĚJKA, P. and TOMEK, A. The Impact of BIM on Risk Management as an Argument for Its Implementation in a Construction Company. Procedia Engineering. 2014, 85(0), pp. 501-509. ISSN 1877-7058. Available from: http://www.sciencedirect.com/science/article/pii/S1877705814019432. https://doi.org/10.1016/j.proeng.2014.10.577

[17] DOBIÁŠ, J. and MACEK, D. Leadership in Energy and Environmental Design (LEED) and its Impact on Building Operational Expenditures. In: Proceedings of the Creative Construction Conference 2014. Creative Construction 2014. Prague, 21.06.2014. Budapest: Diamond Congress Kft. 2014, ISBN 978963-269-434-4.

[18] SCHNEIDEROVÁ HERALOVÁ, R. Life Cycle Cost Analysis in Public Procurement. In: HÁJEK, P., et al., eds. Central Europe towards Sustainable Building 2013. Central Europe towards Sustainable Building 2013. Praha, 26.06.2013 - 28.06.2013. Praha: Grada. 2013, pp. 781-784. ISBN 978-80-247-5018-7. 